\title{
被 \\ SAINS ISLAM DALAM DISKURSUS FILSAFAT ILMU
}

\author{
Mohamad Muslih \\ Program Pascasarjana ISID Gontor \\ Email: muslih@isid.gontor.ac.id
}

\begin{abstract}
Abstrak
Sains Islam sampai saat ini masih terkungkung dalam lingkaran pseudoscience, atau masih pada taraf model justifikasi Bucaillian. Sebagai bangunan keilmuan, sains Islam tentu memiliki basis filosofis. Tulisan ini berupaya mengkaji sains Islam dalam perspektif filsafat ilmu. Dalam perspektif ini, keilmiahan bangunan keilmuan ditentukan oleh ketepatan penggunaan teori dan metodologinya, tanpa mengabaikan sisi sosiologis-historis maupun sisi teologis-metafisis. Jika yang pertama merupakan basis logis dan objektifitas sains, lalu yang kedua merupakan aspek kemanusiaan dari sains, maka yang ketiga adalah basis keyakinan, keimanan, dan keberagamaan dari sains. Dengan ketiga elemen penting tersebut, Sains Islam sebagai sains berbasis agama Islam bisa menjadi ilmiah. Sekalipun demikian, definisi baru Sains Islam sebagai aktivitas ilmiah mesti terus dilanjutkan ke arah "action" dalam bentuk program riset. Dengan begitu, Sains Islam akan menghasilkan temuan-temuan baru, teori baru, metodologi baru, konteks baru, dan seterusnya. Tanpa upaya itu, image pseudosains dan justifikasi Bucaillian akan sulit hilang dari bangunan keilmuan Sains Islam.
\end{abstract}

Abstract

ISLAMIC SAINS IN THE PHILOSOPHY OF SCIENCE DISCOURSE. Islamic science is still confined within the circle of pseudoscience, or still at the level of justification Bucaillian models. As a building of science, Islamic science certainly has a philosophical base. This paper seeks to examine Islamic science in the persectives philosophy of science. In this perspective, the scientific nature of science is determined by the accuracy of the use of theory and methodology, without neglecting the historical and 
sociological aspects as well as the theological and metaphysical facets. If the former is the basis of logic and scientific objectivity, and the second is the humanitarian aspect of science, then the third is the basis of belief, faith, and the diversity of science. With these three essential elements, Islamic science, clerly, can be scientific. Even so, the new definition of Islamic Science as a scientific activity should be implemented in the form of research programs. By doing so, Islamic Science may produce new findings, theories, methodologies, contexts, etc. Without such efforts, the image of pseudoscience and Bucaillian justification will never disappear from the body of Islamic Science.

Kata Kunci: sains Islam; filsafat ilmu; epistemologi

\section{A. Pendahuluan}

Kajian ini berangkat dari asumsi bahwa sains Islam itu memang benar-benar ada, sekaligus menunjukkan compatibilitinya dengan Filsafat Ilmu yang lebih berposisi sebagai landasan filosofis pengembangan ilmu. Harus diakui, bahwa sampai saat ini pengembangan sains Islam belum dapat keluar dari image pseudoscience $^{1}$ atau paling banter tampil dalam model justifikasi Bucaillian, ${ }^{2}$ yang terlihat mencocokkan temuan-temuan sains dengan ayat-ayat kitab suci. Sains Islam memang merupakan sains yang berbasis Islam, tetapi benarkah sains Islam itu tidak ilmiah? Atau mungkinkah sains yang berbasis agama itu menjadi ilmiah?

Beberapa pertanyaan ini sudah tentu tidak cukup jika dijawab dengan menunjukkan fakta sejarah bahwa sains dengan berbagai cabangnya pernah tumbuh dan berkembang dalam tradisi Islam, sekalipun juga dengan menyebut daftar para tokoh saintis

${ }^{1}$ Pseudosains secara sederhana dimengerti sebagai klaim, keyakinan, atau praktek yang disajikan sebagai ilmiah, namun tidak mengikuti metodologi ilmiah yang valid, tidak memiliki bukti pendukung atau masuk akal, tidak dapat diandalkan diuji, atau tidak memiliki status ilmiah. Pseudosains sering dicirikan dengan menggunakan klaim samar-samar, berlebihan atau tidak terbukti, sangat ketergantungan pada konfirmasi daripada upaya penyangkalan secara ketat, kurang keterbukaan untuk evaluasi oleh para ahli lainnya, dan tidak ada proses sistematis untuk mengembangkan teori-teori rasional.

${ }^{2}$ Model ini menggunakan nama Maurice Bucaille, seorang ahli medis Prancis, yang pernah menggegerkan dunia Islam ketika menulis suatu buku yang berjudul "La Bible, le Coran et la Science", yang juga telah diterjemahkan ke dalam bahasa Indonesia. Lihat, Maurice Bucaille, Bibel, Qur'an dan Sains, terj. A. Rasyidi, (Jakarta: Bulan Bintang, 1992). 
muslim yang berjasa besar bagi berkembangnya ilmu pengetahuan di Barat dan di dunia pada umumnya. Jawaban demikian jelas ada nada romantisme dalam melihat sains Islam sebagaimana pernah menemukan kejayaannya di masa lalu, sehingga tidak produktif. Mestinya juga tidak cukup jika dijawab bahwa Islam adalah agama yang mendorong terjadinya penyelidikan ilmiah dan karenanya juga sejalan dengan perkembangan ilmu. Jawaban demikian tampaknya lebih bernuansa teologis dari pada saintific, bahkan ada nada apologetis, terutama jika dihadap-hadapkan (vis a vis) dengan perkembangan sains modern yang western oriented itu.

Sebagai bangunan keilmuan, sains Islam sudah pasti memiliki basis filosofis sebagai kerangka pengembangannya. Maka sudah menjadi keniscayaan bagi sains Islam untuk memasuki diskursus filsafat keilmuan. Bagaimanakah Sains Islam jika dilihat dalam perspektif filsafat llmu ? Inilah pokok pembicaraan makalah ini.

\section{B. Sains Islam dan Problem Demarkasi}

Dalam kajian Filsafat Ilmu, problem demarkasi dipopulerkan oleh Karl R. Popper pada awal abad 20. Popper adalah seorang ahli filsafat ilmu asal Wina Austria yang awalnya bergabung dalam kelompok Vienna Circle yang mengembangkan Positivisme Logis, namun akhirnya berbalik menjadi filsuf yang paling lantang mengkritik pendapat kelompok tersebut. ${ }^{3}$ Inti gagasan Popper ini adalah menemukan garis pemisah antara ilmu dan yang bukan ilmu, antara yang ilmiah dengan yang tidak ilmiah, dengan memberikan kriteria secara ketat terhadap apa yang disebut dengan ilmu (science) itu. ${ }^{4}$ Jika melihat maksud demarkasi ini, sebenarnya bisa juga dikatakan bahwa ia merupakan isu tertua dari filsafat keilmuan, karena sepanjang sejarahnya, refleksi kefilsafatan memang selalu dalam kerangka kebenaran pengetahuan dengan merontokkan "godaan" apa saja yang mengurangi tingkat kebenaran

${ }^{3}$ K. Bertens, Filsafat Barat Abad XX: Inggris-Jerman, (Jakarta: Gramedia, 1983), h. 74-75; lihat juga A, MacIntyre, "Popper, Karl Raimund," dalam The Encyclopedia of Philosophy, Edited by Paul Edwards, (New York: The Macmillan Company and The Free Press, 1967), h. 398.

${ }^{4}$ Alfons Taryadi, Epistemologi Pemecahan Masalah Menurut Karl Popper, (Jakarta: PT Gramedia Pustaka Utama, 1991), h. 49. 
pengetahuan. Tampaknya pokok pembicaraan filsafat semacam ini terus berlangsung hingga hari ini, maka bisa jadi "demarkasi" menjadi persoalan keilmuan sepanjang masa (perennial problem).

Kaitannya dengan Sains Islam, persoalan filsafat keilmuan yang muncul kemudian adalah, apakah Sains Islam dapat lolos dari "ujian" demarkasi ini? Sebagai bangunan keilmuan (scientific building) sudah tentu Sains Islam tidak dapat menghindar untuk tidak memasuki diskursusnya. Maka mau tidak mau, "ujian" demarkasi itu harus dilalui Sains Islam sebagaimana pengetahuan pada umumnya, sekaligus untuk membuktikan bahwa Sains Islam itu juga ilmiah.

Jika dirunut dari awal perkembangan filsafat, pembicaraan tentang hakikat hidup, hakikat realitas, dan hakikat pengetahuan oleh para filsuf klasik, seperti Socrates, Plato, dan Aristoteles, sejarah mencatat, merupakan awal tumbuh kembangnya satu "spesies" pengetahuan filsafat yang membedakan diri dengan "pengetahuan" mitologi yang telah lebih dulu mewabah pada masyarakat manusia. Garis pembedanya, jika yang disebut pertama dapat dijelaskan proses penemuannya, sedangkan yang disebut kedua umumnya berkembang dari generasi ke generasi pada tradisi tertentu, sehingga hanya diterima saja tanpa ada penjelasan yang cukup. Pada tahap ini, problem demarkasi bisa juga dimaknai sebagai genderang perang melawan mitos yang dimengerti tidak memenuhi kriteria pengetahuan yang benar.

"Penjelasan" yang cukup terhadap proses penemuan pengetahuan (untuk ini Popper menyebutnya dengan logic of scientific discovery) tampaknya merupakan kata kunci dari kriteria ilmiah yang paling dasar. Disebut demikian, karena pembicaraan ini sudah dimulai oleh para filsuf Yunani generasi awal sebagaimana disebut di atas. Socrates dan Plato misalnya mengajukan proses "transendensi" untuk menggapai idealisme atau pengetahuan hakiki. ${ }^{5}$ Sedangkan Aristoteles menjelaskannya dengan proses abstraksi untuk membangun konsep yang benar sebelum dibuat suatu proposisi, dan dari proposisi lalu dibuat silogisme. Proses demikian ini menjadi jalan bagi manusia untuk membangun

${ }^{5}$ Verhaak, 'Plato: Menggapai Dunia Idea', dalam Sutrisno F.X Mudji dan F. Budi Hardiman, Para Filsuf Penentu Gerak Zaman, (Yogyakarta: Kanisius, 1994). 
pengetahuan yang benar, yang oleh Aristoteles disebut dengan hylemorphy, ${ }^{6}$ yaitu menyatunya antara form dan matter, antara hukum pikir dengan isi pemikiran. Konsep-konsep kunci dari Aristoteles ini menjadi pembahasan menarik dalam Ilmu Logika/ mantik, suatu ilmu yang membicarakan satu model berpikir yang menjadi basis bagi terbangunnya pengetahuan yang benar. ${ }^{7}$ Maka kata "penjelasan" berarti juga logis atau rasional, karena memang hanya yang logis yang bisa dijelaskan, dan sebaliknya tak akan ada penjelasan untuk hal-hal yang tidak logis.

"Aroma" demarkasi juga tercium oleh para filsuf muslim generasi awal, tak terkecuali juga oleh para mutakallimun (teolog muslim), dan tentu saja juga oleh para teolog Barat di Abad Pertengahan. Maka wajar jika tawaran Aristoteles menjadi sangat mudah diterima, bahkan kemudian menjadi satu mode pemikiran tersendiri yang terkenal dengan masyā'i (peripatetik) yang diidentikkan dengan pemikiran Aristoteles. Beberapa filsuf Muslim seperti al-Kindi, al-Farabi, Ibn Sina, al-Gazali, dan Ibn Rusyd, tidak hanya berjasa mengembangkan ilmu mantiq di dunia Islam, tetapi juga menjadikannya sebagai basis filosofis untuk pengembangan keilmuan yang mereka bangun. ${ }^{8}$ Tidak jauh berbeda dengan apa

${ }^{6}$ Abdullah Sidik, Islam dan Filsafat, (Jakarta: Triputra Masa, 1984), h. 90-91.

${ }^{7}$ Abed al-Jabiri, Bunyah al-'Aql al-Arabi, (Beirut: Markaz Dirāsah al-Waḥdah al-'Arabiyyah, 2004), cet. VIII, h. 13, 251 \& 383.

${ }^{8}$ Dalam bidang Filsafat, karangan al-Kindi pernah diterbitkan oleh Prof. Abu Ridah (1950) dengan judul Rasāil al-Kindi al-Falasifah (Makalah-makalah filsafat al-Kindi) yang berisi 29 makalah. Prof. Ahmad Fuad al-Ahwani pernah menerbitkan makalah al-Kindi tentang filsafat pertamanya dengan judul Kita al-Kindi ilā al-Mu'taș im Billah fì al-Falsafah al-Ola (Surat al-Kindi kepada Mu'tasim Billah tentang filsafat pertama). Karangan-karang al-Kindi mengenai filsafat menunjukkan ketelitian dan kecermatannya dalam memberikan batasan-batasan makna istilah-istilah yang digunakan dalam terminologi ilmu filsafat. Ilmu-ilmu filsafat yang ia bahas mencakup epistemologi, metafisika, etika dan sebagainya. Sebagaimana halnya para penganut Phytagoras, al-Kindi juga mengatakan bahwa dengan matematika orang tidak bisa berfilsafat dengan baik.

Sedang di antara karya al-Farabi adalah Kitab Ihașā’ al-'Ulūm. Dengan karyanya itu, dia digelari Guru Kedua. Lihat Osman Bakar, Hierarki Пmu Membangun Rangka Pikir Islamisasi Ilmu, (Bandung: Mizan,1997), h. 47. Edisi bahasa Indonesianya sebagian sudah diterjemahkan oleh Nurcholish Madjid. Lihat Nurcholish Madjid, Khazanah Intelektual Nurcholish Islam, (Jakarta: Bulan Bintang,1984), h. 121-133. Dalam bahasa Latin disebut De Scientiis yang diakui sebagai klasifikasi pertama yang 
yang terjadi pada para filsuf Yunani di atas, karya-karya para filsuf Muslim yang sarat mantiq ini juga kemudian menjadi semacam pencerahan di tengah-tengah tradisi nujūm dan kahn yang menjadi spirit dari karya syair dan karya-karya mitologi lainnya. Demikian juga bagi para mutakallimun, mantiq kecuali digunakan untuk membangun argumen dan keilmuan juga menghindari kesesatan berpikir dalam menghadapi "lawan" debatnya. Hal yang kurang lebih sama juga terjadi pada para teolog Barat. Intinya, penjelasan logis terhadap proses penemuan, menjadi garis pemisah antara ilmu dan yang bukan ilmu, yang kala itu didominasi oleh mitos.

dikenal luas oleh kaum Muslimin. Dengan judul: el-Farabi de divisione philosophiae, karya ini tersimpan dalam Oxford Catalog. Mss. Angl. Tom. I. Pars I. h.81 No. 1677; h.140 No. 2590; h. 285 No. 6341; Pars II., h. 50 No. 1553. Lihat Syamsuddin Arif, 'Transmigrasi Ilmu': Dari Dunia Islam ke Eropa, dalam Tsaqafah, Jurnal Peradaban Islam, Vol. 6, No. 2, Oktober 2010.

Sementara di antara karya Ibnu Sina dalam bidang filsafat adalah kitab asy-Syifa'. Asy-Syifa' ditulis dalam 18 jilid yang membahas ilmu filsafat, mantiq, matematika, ilmu alam dan ilahiyyat. Mantiq asy-Syifa' saat ini dikenal sebagai buku yang paling otentik dalam ilmu mantiq islami, sementara pembahasan ilmu alam dan ilahiyyat dari kitab asy-Syifa' sampai saat ini juga masih menjadi bahan telaah.

al-Gazali dalam bidang ini mengarang buku al-Mustasyfa min $\mathrm{Ilm}$ al-Ușūl, (Qahirah: Maktabah al-Amiriyyah, 1904), yang kemudian disunting oleh Dr. Muhammad Sulayman al-Asyqar, al-Mustasyfa, (Bairut: Mūassasah al-Risālah, 1997) merupakan sebuah karya yang mensintesiskan antara Mantiq dengan pembahasan 'Ilm Usul al-Fiqh. Beberapa kajian menunjukkan bahwa dalam kitab itu Gazali bermaksud menunjukkan bahwa mantik merupakan muqaddimah bagi ilmuilmu yang lain. Lihat misalnya Mohd Fauzi bin Hamat, "Kedudukan Mantiq sebagai Mukaddimah Ilmu: Satu Analisis Pandangan Imam al-Gazali”, dalam Afkar, Jurnal Akidah \& Pemikiran Islam, Bil. 3: Rabiu al-Awwal 1423/Mei-Jun 2002, ph. 33-56.

Terkait dengan Ibn Rusyd, Herny Corbin memberikan testimoni bahwa Ibn Rusyd adalah "the most eminent representative of what has been called Arab philosophy", yakni representasi paling unggul dari filsafat Arab. Lihat Henry Corbin, History of Islamic Philosophy, (London and New York: Kegan Paul International, 1962), h. 242. Dalam salah satu karyanya, Ibn Rusyd menegaskan bahwa kebenaran dapat dipetik dimana-mana; kebenaran terdapat dalam Islam dan filsafat Yunani. Di antara pernyataannya: "Kebenaran-kebenaran itu tidak saling bertentangan tetapi saling menguatkan satu sama lain". "Kita harus memungut metodologi dari para pendahulu meskipun berasal dari penganut agama lain". "Kita wajib membaca buku-buku filosof pendahulu. Jika ada kebenaran maka kita terima. Jika ada kesalahan maka kita tolak”. Lihat Ibn Rusyd, Faṣl al-Maqāl fì Taqrīr mā Bayn al-Syarīah wa al-Hikmah min al-Ittișāl, tahqiq Abid al-Jabiri, (Libanon: Markaz Dirāsah al-Wahdah al-Arabiyah, 2007), h. $91 \& 96$. 
Lahirnya Renaisance pada abad ke-16 adalah akhir dari abad Pertengahan sekaligus menandai lahirnya masyarakat modern dengan Rene Descartes sebagai juru bicaranya. Sejak itu, hasil kreatifitas alam pikir Abad Pertengahan diruntuhkan satu persatu. Semua makna dunia objektif tradisional dipertanyakan dan disangsikan secara metodis, sehingga Descartes sampai pada suatu kesimpulan: cogito ergo sum (aku berpikir maka aku ada). Penyangsian secara radikal untuk mencapai kesadaran murni nan sejati inilah hakikat pengetahuan yang digagas Descartes. ${ }^{9}$ Maka kabar apapun dan dari manapun termasuk dari tradisi, budaya, dan agama, jika tidak lolos dari ujian "penyangsian" akan ditolak, sebaliknya jika dapat lolos dari ujian rasional ini akan diterima sebagai kebenaran.

Apa yang ditemukan Descartes pada taraf epistemologis ini adalah peranan mutlak subjek dalam membentuk realitas. Maka dalam sejarah epistemologi, filsuf ini telah membawa isu pengetahuan dari wilayah objek ke subjek. Subjeklah yang membangun dan menciptakan realitas yang diketahui, sehingga menjadi ada. Penekanan pada sisi subjek ini berkembang terus dalam filsafat rasionalis Prancis dan Jerman, dari Descartes melewati Leibniz sampai pada Kant di satu pihak, tetapi juga dalam tradisi Anglo-Saxon yang epistemologinya lebih berorientasi psikologis, seperti tampak dalam filsafat Hobbes, Locke, Berkeley, dan Hume di lain pihak.

Adalah jasa Immanuel Kant yang bukan hanya meradikalkan penekanan Descartes atas subjek, melainkan juga memperlihatkan the conditions of possibility dari pikiran manusia. Seperti kita ketahui, konsepsi Kant tentang proses pengetahuan manusia adalah suatu proses sintesa antara apa yang ia sebut dengan apriori dan aposteriori. Yang pertama merupakan aktivitas rasio yang aktif dan dinamis dalam membangun dan berfungsi sebagai bentuk (form) pengetahuan, yang terdiri dari kategori-kategori, ${ }^{10}$ sedang yang

${ }^{9}$ Dengan metode kesangsian (le doute methodique), menurut Descartes, akan ditemukan yaitu kebenaran dan kepastian yang tak tergoyahkan karena saya mengertinya secara jelas dan terpilah-pilah (claire et distincte, clearly and distinctly). Lihat Bernard Williams, "Rene Descartes", dalam Paul Edwards (editor), The Encylopaedia of Philosophy, Volume I and II, 1992, h. 345.

${ }^{10}$ Menurut Kant ada dua belas kategori di dalam akal budi. Kategori- 
kedua merupakan serapan pengalaman yang berfungsi sebagai 'isi' (matter) pengetahuan, yang terdiri dari fenomena objek. Dengan begitu, bagi Kant, pengetahuan, hakikatnya adalah konstruksi apriori manusia. Sebagai konsekuensi cepatnya rasio manusia dalam mengkonstruk pengetahuan, maka Kant menyimpulkan, tidak mungkin pengetahuan manusia menjangkau noumena atau das ding an sich (kenyataan pada dirinya). ${ }^{11}$

Singkat kata, di tangan Descartes, Hume hingga Kant ini ilmu pengetahuan dibawa kepada problem epistemologis, yaitu kerangka berpikir ilmuwan dan batas-batasnya sehingga mampu melahirkan pengetahuan yang benar. Persoalannya kemudian, bagaimana konstruksi epistemologi Sains Islam itu, atau setidaknya, dapatkah ia berhasil melalui kritik epistemologi ini. Sekalipun isu ini sudah tidak begitu populer pada ilmu pengetahuan kontemporer, namun tetap membuat bangunan keilmuan Sains Islam tidak bisa dipahami secara sederhana, apalagi tanpa pertimbangan-pertimbangan epistemologis semacam ini.

Setelah isu epistemologi, tampaknya "logika induksi" yang ditawarkan Francis Bacon di satu sisi ${ }^{12}$ dan "metodologi ilmiah" yang ditawarkan August Comte di sisi yang lain, bisa dikatakan sebagai upaya untuk membangun norma-norma ilmiah dalam kegiatan keilmuan. Menurut Bacon, dalam menjalankan aktifitas ilmiah, para saintis mesti menghindari empat godaan yang oleh Bacon disebut dengan "idola", yaitu idola tribus, idola specus, idola fori, dan idola teatri. ${ }^{13}$ Sementara Comte yang lebih berfokus pada

kategori yang bersifat asasi adalah kategori yang menunjukkan kuantitas (kesatuan, kejamakan, keutuhan); kualitas (realitas, negasi, dan pembatasan); relasi (substansi dan aksidensi, sebab-akibat (kausalitas, interaksi); modalitas (mungkin-mustahil, ada-tiada, keperluan-kebetulan). Lihat Immanuel Kant, Critique of Pure Reason, Translated by JMD. Meiklejohn, (New York: Prometheus Books, 1990), h. 61.

${ }^{11}$ Untuk lebih mamahami konsepsi Kant ini, lihat M. Muslih, Filsafat Ilmu; Kajian atas Asumsi Dasar, Paradigma, dan Teori Dasar Ilmu Pengetahuan, (Yogyakarta: Belukar Budaya, 2005), khususnya pada bab "Kritisisme Kant".

${ }^{12}$ Dengan logika induksi, Fr. Bacon mengkritik logika deduksi Aristotelian sebagai tidak mengantarkan memperoleh pengetahuan yang baru. Untuk maksud itu Bacon menulis Novum Organun sebagai tandingan Organon Aristoteles.

${ }^{13}$ Menurut Bacon terdapat empat macam idola: pertama adalah Idols of the Tribe (=Bangsa), adalah semacam prasangka yang dihasilkan tanpa pertimbangan yang matang sebagaimana terjadi pada kebanyakan orang awam (tribus), sehingga 
sosiologi memusatkan perhatiannya pada pengetahuan inderawi. Kata 'positif' atau positivisme adalah simbol dari norma dimaksud. Pengetahuan manusia hendaknya tidak melampaui fakta objektif, karena peran subjek tidak lebih dari sekedar instrumen untuk menyalin fakta objektif tersebut. Dalam positivisme, pendulum epistemologis bergerak ke pihak objek lagi, namun objek dimaksud bukanlah objek spekulatif sebagaimana tampil dalam Abad Pertengahan, tetapi objek inderawi. Isu utama yang dibawa positivisme adalah problem metodologi. Karenanya, objek dalam positivisme masih dipersempit dengan standar metodologi. Dengan kata lain, 'pengetahuan' dapat dikatakan ilmiah jika menggunakan fakta positif dan yang digali dengan metodologi ilmiah. ${ }^{14}$ Di sini terlihat, bahwa problem demarkasi mengalami pergeseran dari persoalan epistemologi ke persoalan metodologi.

Sampai hari ini metodologi menjadi persoalan penting dalam dunia ilmiah. Ini artinya, gagasan August Comte itu cukup kuat, karenanya masih bertahan sebagai standar ilmiah. Hal ini tidak bisa dilepaskan dari jasa kelompok Lingkaran Wina (Vienna Circle), yang dengan sangat gigih, mendukung pandangan positivisme. Sudah tentu fakta positif dan metodologi ilmiah, mereka setujui sebagai standar ilmiah, namun mereka menambahkan satu lagi, yaitu bahasa ilmiah berupa "proposisi" sebagai standar berikutnya. Untuk itu mereka membedakan pernyataan "yang bermakna" (meaningful) dan "yang tak bermakna" (meaningless). Hanya pernyataan yang meaningful yang ilmiah, sedang yang meaningless sudah tentu tidak ilmiah. Mereka menawarkan prinsip "verifikasi" sebagai garis pemisah antara proposisi yang meaningful dengan yang meaningless. Hanya proposisi yang dikeluarkan oleh sains, yaitu mengenai data-

menjadi semacam prasangka kolektif. Kedua, Prasangka Individual atau Idols of the Cave. Yang dimaksudkan di sini adalah pengalaman-pengalaman dan minat-minat pribadi kita sendiri mengarahkan cara kita melihat dunia, sehingga dunia objektif dikaburkan. Ketiga: Idola Fora (Forum=Pasar) atau Idols of the Marketplace adalah idola yang paling berbahaya. Yang diacu di sini adalah pendapat atau kata-kata orang yang diterima begitu saja sehingga mengarahkan keyakinan-keyakinan dan penilaian-penilaian kita yang tak teruji. Keempat: Idola Theatra (=panggung) atau idols of the theatre. Dengan konsep ini, Bacon memperlihatkan sistem-sistem filsafat tradisional adalah kenyataan subjektif para filsufnya. Sistem-sistem ini dipentaskan, lalu tamat, seperti sebuah teater.

${ }^{14}$ Uraian lebih luas lihat M. Muslih, Filsafat Ilmu... 
data yang dapat diobservasi, yang dapat dimasukkan ke dalam wilayah yang "bermakna". Sementara semua pernyataan yang tidak dapat dibuktikan kebenarannya secara empiris berdasarkan "asas verifikasi”, dimasukkan ke dalam wilayah non-sense. Termasuk ke dalamnya adalah estetika ("lukisan itu indah"), moral ("perbuatan itu tak adil”), dan metafisika ("tuhan itu mahakuasa"). Dengan tesis ini, Lingkaran Wina menyingkirkan pencarian makna dalam agama sebagai non-sense.

Beberapa prinsip ini memberikan andil besar bagi tereliminasinya sistem pengetahuan lain dan sistem kebenaran lain yang berada di luar jangkauan standar ilmiah itu, seperti metafisika, seni, tradisi dan lebih-lebih agama. Konsekuensinya, jika ingin disebut ilmiah, maka metafisika, seni, tradisi dan termasuk agama harus mengikuti patok-patok ilmiah secara rigid sebagaimana sains. Di sini derajat sains memang menjadi lebih tinggi dari segalanya. Maka Sains Islam sebagai bangunan keilmuan yang berbasis agama, akan sangat sulit memasuki diskursusnya, atau paling tidak perjuangan penuh liku harus terlebih dulu dilaluinya.

Dalam karya Logic of Scientific Discovery, Karl R. Popper masuk dalam diskusi "demarkasi" itu untuk "menyelamatkan" posisi agama dalam pencarian makna atau setidaknya, baik agama maupun sains beroperasi dalam wilayah berbeda dalam pencarian makna. Menurut Popper, garis pemisah antara pernya-taan yang bermakna dan yang tidak bermakna sebagai kriteria ilmiah itu sebagaimana Lingkaran Wina itu tidak bisa diterima. Ia pun membuat demarkasi baru dengan kriteria "asas falsifikasi", yaitu demarkasi antara teritorium ilmiah dan non-ilmiah. ${ }^{15}$ Semua pernyataan yang dapat difalsifikasi adalah ilmiah, sementara yang tak dapat difalsifikasi adalah non-ilmiah. Di sini Popper "mengembalikan" posisi agama sebagai pengetahuan yang sahih dalam pencarian makna, karena menurutnya pernyataan-pernya-taan yang tak bisa difalsifikasi memang tidak ilmiah dan bukan termasuk dalam wilayah sains, tetapi pernyataan itu bukan berarti tidak bermakna.

Di sini, Popper membedakan antara yang ilmiah dengan yang bermakna. Memang pernyataan etika, estetika, metafisika,

${ }^{15}$ Karl R. Popper, Logic of Scientific Discovery, (New York: Harper and Row, Harper Torchbooks, 1965). 
dan agama itu tidak ilmiah, tetapi bukan berarti tidak bermakna. Karena kriteria ilmiah, bagi Popper sudah jelas, yaitu criticable, testable, dan falsifiable. Maka bangunan keilmuan apapun, termasuk Sains Islam adalah sains biasa, temuan ilmuwan [muslim] yang sarat kritik, ujian, dan kesalahan. Untuk itu, Popper memaknai teori cukup sebagai hipotesa, yaitu kesimpulan sementara yang harus terus menerus diuji tingkat kebenarannya.

Beberapa kriteria ilmiah sebagaimana ditawarkan oleh positivisme Comte, positivisme logis Vienna Circle, dan Falsi-fikasi Popper telah membuat sains dianggap sebagai sistem pengetahuan yang paling objektif karena tak tercampuri nilai subjektifitas apapun. Kondisi ini menarik Thomas S. Kuhn untuk melakukan pembongkaran terhadap sisi-sisi historisitas sains. Dalam penelusurannya terhadap sejarah sains, Kuhn melihat, di balik teori dan metodologi yang berperan pada wilayah logika itu ternyata ada paradigma. Paradigma ilmiah adalah pola pikir kolektif komunitas ilmiah (scientific community) yang menjadi basis tumbuh kembangnya teori dan metodologi. Paradigma memang pola pikir atau pemikiran, tetapi berbeda dengan form atau hukum-hukum pikir sebagaimana logika Aristetotelian, juga berbeda dengan apriori Cartesian dan Categori Kantian yang mengandaikan objektivisme dan universalisme pemikiran, berbeda pula dengan teori dan metodologi positivistik yang bercorak saintisme, paradigma merupakan pemikiran yang terbentuk secara kolektif, sehingga bersifat historis, sosiologis dan antropologis. Dalam pengertian yang lebih spekulatif, paradigma Kuhnian dapat diidentikkan dengan konsep episteme Michel Foucault. ${ }^{16}$ Sedang dalam pengertian yang lebih luas, paradigma bisa disamakan dengan konsep 'aql mukawwan Abid al-Jabiri, yang tidak saja menjadi basis tumbuh kembangnya ilmu, tetapi juga menjadi basis tumbuh kembangnya tradisi, budaya, dan peradaban, bahkan menentukan perjalanan sejarah. ${ }^{17}$

\footnotetext{
${ }^{16}$ Episteme merupakan keseluruhan ruang makna dan prapengandaian yang mendasari kehidupan yang memungkinkan pengetahuan bisa terlahir. Maka episteme berisi hal-hal yang bisa dipikirkan dan dipahami pada suatu masa. Michel Foucault lebih jauh melihat, episteme merupakan 'medan' penelusuran epistemologis dari kelahiran pengetahuan. Lihat Michel Foucault, The Order of Think: An Archeology of Human Sciences, (New York: Vintage Books, 1994), h. xxii.

${ }^{17}$ Abed al-Jābiri, Takwin al-'Aql al-'Arabi, (Beirut: Markaz Dirāsah al-Waḥdah
} 
Paradigma memang kontribusi paling penting dari Kuhn pada dunia keilmuan. Dengan paradigma ini, Kuhn tercatat telah berhasil membawa sains ke wilayah sejarah. Sebagai produk komunitas ilmiah, keberadaan paradigma tidak hanya ditentukan oleh ketepatannya dalam menyelesaikan teka-teki ilmiah (sientific puzzle) tetapi juga menjadi sangat tergantung dengan "kesetiaan" para ilmuwan dalam memegangi nilai bersama. Sama seperti dunia politik dan praktik-praktik manusiawi lainnya, sains juga kontingen terhadap sejarah dan komunitas ilmuwan sehingga kebenaran makna ilmiah pun bisa berubah secara revolusioner seperti dalam politik.

Pada wilayah paradigma ini, historisitas sains menjadi terbukti, karena memang ada beberapa faktor lain di luar keilmuan yang menjadi bagian tak terpisahkan dalam bangunan keilmuan, seperti faktor ekonomi, politik, budaya, bahkan ideologi. Maka semakin membuka jalan bagi masuknya berbagai nilai dalam bangunan keilmuan sains, termasuk nilai etis-religious sebagaimana dicita-citakan Sains Islam.

\section{Sains Islam dan Problem "Progress of Science"}

Seperti telah diuraikan di atas, bahwa Thomas Kuhn telah membawa sains ke wilayah sejarah. Untuk itu Kuhn melihat pentingnya Fisafat Ilmu berguru pada sejarah ilmu, sebagai upaya menelusuri proses pembentukan paradigmanya, ${ }^{18}$ sekaligus mengetahui perkembangannya. Dari sinilah "progress of science" kemudian menjadi isu penting dari Filsafat Ilmu, yang intinya membicarakan, bagaimana sains bisa dikatakan berkembang. Jawaban dari pertanyaan ini kemudian menjadi asumsi bagi pengembangan sains. Artinya, pandangan terhadap perkembangan sains ini, akan sangat menentukan upaya pengembangannya. Para penganut positivistik melihat bahwa ilmu berkembang jika suatu teori dapat terbukti. Jika ditemukan banyak bukti, maka teori semakin kuat, pada saat itulah ilmu mengalami perkembangan.

al-Arabiyyah, cet. VIII, 2002), h. 5-6 \& 13-16.

${ }^{18}$ Dalam diskursus pemikiran Islam kontemporer, proses pembentukan paradigma ini identik dengan konsep takwin (takwin al-aql) sebagaimana dipopulerkan oleh Muhammad Abed al-Jābiri. 
Perkembangan ilmu sangat tergantung dengan proses akumulasi bukti. Maka sudah bisa dibayangkan, bahwa tugas ilmuwan dalam pengembangan sains pada umumnya adalah menggali dan menemukan bukti sebanyak-bayaknya dengan berlandaskan pada teori tertentu. Untuk itu, kebenaran teori kemudian menjadi faktor dominan bagi kebenaran sains, bahkan teori menjadi penentu bagi jalannya proses pembuktian. Untuk menghindari kesalahan, umumnya pilih-pilih fakta yang mendukung teori tampaknya sudah menjadi rahasia umum.

Dengan proses seperti itu, upaya justifikasi teori oleh normanorma agama, sebagaimana "sains Islam" yang mengambil corak Bucailian, tidak begitu beresiko, karena proses pengembangan ilmu tidak lain merupakan proses pembuktian teori. Sekalipun demikian, bukan berarti tidak memiliki kelemahan. Memang, jika teori benar, menumpuknya bukti berarti memperkokoh kebenaran, sebaliknya jika teori kemudian diketahui salah, maka akumulasi bukti berarti juga memperkokoh kesalahan.

Begitulah kelemahan positivistik dalam hal pengembangan sains, setidaknya sebagaimana dilihat Popper. Bagi Popper pengembangan sains model positivistik, bukan saja mengandung kelemahan, tetapi bahkan jauh untuk disebut ilmiah. Karena kenyataaanya, membuktikan teori bukanlah pekerjaan yang membutuhkan kecakapan ilmiah tertentu. Untuk itu Popper menawarkan proses pengembangan sains dengan melakukan upaya serius untuk membuktikan salah (falsifikasi). Jika suatu proposisi umpamanya menyatakan "semua angsa berwarna putih", maka proses ilmiah yang dilakukan adalah berusaha semaksimal mungkin untuk menggugurkannya, misalnya dengan menemukan angsa berwarna lain atau dengan eksperimen kawin silang atau bisa jadi dengan sistem kloning.

Sebagai konsekuensi dari pandangannya bahwa teori itu pada dasarnya adalah hipotesa yang testable dan falsifiable, Popper melihat bahwa sains baru dikatakan berkembang jika suatu teori gugur, tidak bertahan oleh proses falsifikasi, sehingga digantikan oleh teori yang lebih kuat. Maka begitulah, di tangan Popper, teori itu dapat tumbuh, dapat tambah kokoh, bahkan dapat tumbang. Di sini Popper, menempatkan kritik dan penyangkalan (refutability) 
sebagai bagian terpenting dari tradisi ilmiah yang mesti terbangun. Maka jika dikaitkan dengan bangunan keilmuan yang berbasis agama, seperti sains Islam, sudah tentu pandangan Popper ini berkonsekuensi pada kokoh dan tumbangnya segala nilai yang baik langsung maupun tak langsung dikaitkan dengan teori yang bersangkutan. Misalnya pada pengembangan sains model justifikasi teori oleh ayat-ayat kitab suci, jika proses kritik dan penyangkalan itu berakhir dengan tumbangnya teori, maka berbagai ayat yang mengiringinya, mau tidak mau, juga ikut tumbang. Inilah kesulitan pengembangan sains model justifikasi teori, yang harus dicarikan jalan keluarnya, terutama terkait posisi "basis agama" sebagai bagian tak terpisahkan dari bangunan keilmuan sains.

Pengembangan sains yang bertumpu pada teori, seperti pembuktian teori Vienna Circle dan penyangkalan teori Popper, membuat perkembangan sains berlangsung linier, homogen, dan rasional. Model seperti ini mendapat kritikan dari Kuhn sebagai tidak berkembang. Dalam analisisnya atas sejarah perkembangan sains, Kuhn menunjukkan bahwa perkembangan sains tidak berlangsung linier, homogen, dan rasional seperti itu. Kuhn melihat, sains berkembang melalui revolusi ilmiah dengan membongkar paradigma lama dan menggantinya dengan yang baru. Apa yang dipandang benar dalam paradigma lama akan mengalami krisis sampai ditegakkan suatu paradigma baru dengan kebenarankebenaran baru di dalamnya. ${ }^{19}$ Yang sentral di sini adalah pandangan bahwa perubahan paradigma dalam sejarah sains bukan masuk dalam wilayah logis hukum-hukum alam, melainkan terjadi seperti proses "metanoia" (pertobatan) dalam agama. Ini membuat teoriteori dalam paradigma yang satu tak dapat dibandingkan dengan teori-teori dalam paradigma yang lain..$^{20}$

Lebih radikal dari pada Popper, Kuhn berhasil menunjukkan bahwa sains memiliki kesamaan dengan dunia politik sehingga kebenaran ilmiah dapat berubah secara revolusioner, bukan evolusi

${ }^{19}$ Thomas S. Kuhn, The Structure of Scientific Revolution, (Chicago: The University of Chicago Press, 1970).

${ }^{20}$ Lebih jauh baca Gurry Gutting (Ed.), Paradigms and Revolutions: Appraisals and Applications of Thomas Kuhns Philosophy of Science, (Notre Dame: University of Norte Dame Press, 1980). 
atau akumulatif sebagaimana anggapan sebelumnya. Perkembangan ilmu itu tidak disebabkan oleh dikuatkan dan dibatalkannya suatu teori, tetapi lebih disebabkan oleh adanya pergeseran paradigma. Paradigma pada dasarnya adalah hasil konstruksi sosial para ilmuwan (komunitas ilmiah), yang merupakan seperangkat keyakinan meraka sebagai cara pandang terhadap dunia dan contohcontoh prestasi atau praktek ilmiah konkrit.

Berbeda dengan teori yang perkembangannya dapat menjadi semakin kokoh atau malah tumbang digantikan oleh teori yang lebih kuat, pergeseran paradigma (shifting paradigm) yang menyebabkan terjadinya revolusi ilmiah berlangsung melalui beberapa tahapan, pertama, tahap ilmu normal (normal science), di mana paradigma ilmiah membimbing dan mengarahkan aktivitas ilmiah. Di sini para ilmuwan berkesempatan menjabarkan dan mengembangkan paradigma sebagai model ilmiah yang digelutinya secara rinci dan mendalam. Bersamaan dengan itu, para ilmuwan juga berusaha semaksimal mungkin untuk mempertahankan segenap teori yang diakuinya sebagai kebenaran dari serangan kritik, refutasi dan falsifikasi. Kedua adalah tahap anomali (keganjilan). Pada tahap ini para ilmuwan menjumpai berbagai fenomena yang tidak dapat diterangkan dengan paradigma yang digunakan sebagai bimbingan atau arahan aktivitas ilmiahnya. Dalam tahap ini para ilmuwan menunjukkan sikap kritis terhadap paradigma yang selama ini diakuinya. Anomali adalah suatu keadaan yang memperlihatkan adanya ketidakcocokan antara kenyataan (fenomena) dengan paradigma yang dipakai.

Tahap ketiga adalah tahap krisis. Menumpuknya anomali, sebagai akibat dari sikap kritis komunitas ilmiah, menimbulkan krisis kepercayaan terhadap paradigma. Paradigma mulai diperiksa dan dipertanyakan. Para ilmuwan mulai keluar dari jalur ilmu normal. Tahap keempat, para ilmuwan mulai mengembangkan suatu paradigma tandingan yang dipandang bisa memecahkan masalah dan membimbing aktivitas ilmiah berikutnya. Proses peralihan dari paradigma lama ke paradigma baru inilah yang dinamakan revolusi ilmiah (scientific revolution).

Pandangan Kuhn, terutama pada tahap sains normal ini jelas akan menyulitkan proses falsifikasi dalam pengembangan sains, 
karena pasti akan mendapat penolakan oleh para ilmuwan, atau paling tidak kondisi itu akan dipertahankan sekuat tenaga. Artinya, jika falsifikasi dilanjutkan berarti sains normal itu sebenarnya tak akan pernah terwujud, dan sebaliknya jika sains nomal itu ada, maka proses falsifikasi itu juga hanyalah akal-akalan saja. Perdebatan antara falsifikasi Popperian dan revolusi ilmiah Kuhnian ini yang kemudian menarik Imre Lakatos untuk menawarkan gagasan "Metodology of Scientific Research Programmes" sebagai kritik sekaligus pengembangan terhadap kedua pemikiran itu. Berbeda dengan Kuhn yang memberikan kemungkinan terjadinya revolusi sebagai sesuatu yang luar biasa dalam perkembangan sains, Lakatos justru tidak melihat perkembangan sains terjadi dengan revolusi. Menurut Lakatos, perkembangan sains dapat terjadi melalui kontinuitas. Bahkan jika sebuah program riset terfalsifikasi, program tersebut tidak lantas terpuruk, tetapi ia masih memiliki kekuatan untuk bangkit kembali guna meraih kemapanan. ${ }^{21}$

Tawaran Lakatos "Metodologi Program Riset" dimaksudkan sebagai struktur metodologis yang memberikan bimbingan untuk riset masa depan dengan cara positif dan negatif. Menurut Lakatos, persoalan pokok yang berhubungan dengan logika penemuan (Logic of Discovery) tidak bisa dibahas secara memuaskan kecuali dalam kerangka metodologi program riset. Dalam program riset ini terdapat aturan-aturan metodologis yang disebut dengan "heuristik", yaitu kerangka kerja konseptual sebagai konsekuensi dari bahasa ilmiah. Heuristik itu adalah suatu keharusan untuk melakukan penemuanpenemuan lewat penalaran induktif dan percobaan-percobaan sekaligus menghindarkan kesalahan dalam memecahkan masalah.

Pemahaman terhadap sejarah ilmu pengetahuan adalah sejarah program riset yang lebih dari sekedar teori. Menurut Lakatos, ada tiga elemen yang harus ada dalam suatu program riset, yaitu: pertama, "inti pokok" (hard-core), dalam hal ini asumsi dasar yang menjadi ciri dari program riset ilmiah yang melandasinya, yang tidak dapat ditolak atau dimodifikasi. "inti pokok" ini dilindungi dari ancaman falsifikasi. ${ }^{22}$ Dalam aturan metodologis program riset,

${ }^{21}$ Imre Lakatos dan Alan Mosgrave (Ed.), Criticism and the Growth of Knowledge, (Cambridge: Cambridge University Press, 1974), h. 92-93.

${ }^{22}$ Ibid., h. 135. 
hard-core ini disebut sebagai heuristik negatif, yaitu "inti pokok" yang menjadi dasar bagi elemen yang lain. Demikian ini, karena sifatnya yang menentukan dari suatu program riset dan sebagai hipotesa-teoretis yang bersifat umum, maka posisinya sebagai dasar bagi program pengembangan ilmu.

Kedua, "lingkaran pelindung" (protective-belt) yang terdiri dari hipotesa-hipotesa pendukung (auxiliary hypotheses) dalam kondisi-kondisi awal. Dalam mengartikulasi hipotesa pendukung, lingkaran pelindung ini harus menahan berbagai serangan, pengujian dan memperoleh penyesuaian, bahkan perubahan dan pergantian, demi mempertahankan hard-core. Dalam aturan metodologis program riset, protective-belt ini disebut "heuristik positif". Heuristik ini dimaksudkan untuk menunjukkan bagaimana "inti pokok" program riset dilengkapi agar dapat menerangkan dan meramalkan fenomena-fenomena yang nyata. Heuristik positif terdiri dari seperangkat saran atau isyarat tentang bagaimana mengembangkan varian-varian yang kompleks; bagaimana memodifikasi dan meningkatkan lingkaran pelindung yang fleksibel. Dengan demikian suatu teori selalu dapat dilindungi dari ancaman falsifikasi dengan mengalihkan sasaran falsifikasi kepada asumsi-asumsi lain yang kompleks. Sehingga suatu teori sebagai suatu struktur yang koheren, namun tetap terbuka untuk dikembangkan (open-ended) dan memberikan kesempatan untuk mengadakan program riset lebih lanjut.

Ketiga, serangkaian teori (a series theory), yaitu keterkaitan teori di mana teori yang berikutnya merupakan akibat dari klausul bantu yang ditambahkan dari teori sebelumnya. Untuk itu, bagi Lakatos, yang harus dinilai sebagai ilmiah atau tidakilmiah bukanlah teori tunggal, melainkan rangkaian beberapa teori. Yang terpenting dari serangkaian perkembangan ilmu dan rangkaian teori adalah ditandai oleh kontinuitas yang pasti. Kontinuitas ini berangkat dari program riset yang murni. Keilmiahan sebuah program riset dinilai berdasarkan dua syarat: (1) suatu program riset harus memenuhi derajat koherensi yang mengandung perencanaan yang pasti untuk program riset selanjutnya; (2) suatu program riset harus dapat menghasilkan penemuan fenomena baru.

Dengan struktur program riset itu diharapkan dapat 
menghasilkan perkembangan ilmu yang rasional. Keberhasilan suatu program riset dilihat dari terjadinya perubahan problem yang progresif. Sebaliknya, suatu program riset dikatakan gagal jika hanya menghasilkan problem yang justru merosot atau degenaratif.

Dalam pelaksanaannya, metodologi program riset ilmiah ditelaah dari dua sudut pandang, yang satu berhubungan dengan pekerjaan program riset tunggal itu sendiri, sedangkan yang lain dibandingkan dengan program riset saingannya. Program riset tunggal meliputi perluasan-perluasan dan modifikasi perluasan lingkaran pelindung dengan menambah atau menguraikan berbagai macam hipotesa pendukung. Modifikasi atau penambahan terhadap lingkaran pelindung dari suatu program riset harus dapat diuji secara independen. Para ilmuwan baik individu maupun kelompok bebas mengembangkan lingkaran pelindung, asalkan memberi peluang bagi pengujian baru yang akan membuka kesempatan bagi penemuan-penemuan baru. Dengan demikian, dalam metodologi program riset, Lakatos menolak adanya hipotesa-hipotesa yang bersifat ad hoc yang tidak dapat diuji secara independen, dan menolak upaya yang memperkosa "inti pokok" program.

\section{Basis Filosofis Sains Islam}

Berdasarkan uraian di atas, ternyata proses dan hasil keilmuan pada jenis ilmu apapun, ternyata sangat ditentukan oleh landasan filosofis yang mendasarinya, yang memang berfungsi memberikan kerangka, mengarahkan, menentukan corak dari keilmuan yang dihasilkannya. Landasan filosofis dimaksud adalah kerangka teori (theoretical framework), paradigma keilmuan, dan asumsi dasar. Ketiga hal inilah yang lazim disebut dengan filsafat ilmu atau filsafat keilmuan, dalam arti, basis filosofis yang mendasari bangunan keilmuan dan aktifitas ilmiah pada umumnya. "Kerja" ketiga landasan filosofis ini, memang tidak serta merta bisa ditunjukkan dalam wilayah praktis, namun jelas sangat menentukan 'corak' ilmu yang dihasilkan. Dalam sejarah perkembangan ilmu, ketiga hal ini memiliki keterkaitan tidak saja historis, tetapi juga sistematis. Disebut demikian, karena suatu paradigma tertentu lahir berdasarkan asumsi dasar tertentu, begitu pula teori tertentu bekerja tidak keluar dari ‘wilayah’ paradigmanya. 


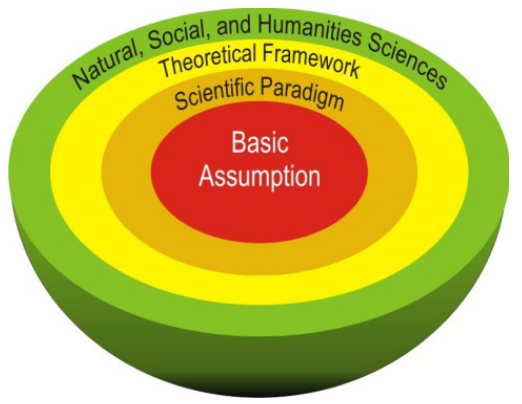

Dari diagram sederhana di atas bisa dilihat bahwa semua cabang ilmu (ilmu alam, ilmu sosial, dan ilmu humanities) sangat ditentukan oleh kerangka teori (theoretical framework) yang mendasarinya, yang 'wilayahnya' lebih umum, abstrak dan filosofis, sementara kerangka teori lahir dan berdiri di atas basis paradigma tertentu yang sifatnya juga lebih abstrak dan filosofis lagi, begitu pula paradigma tertentu juga tergantung dari asumsi-asumsi yang mendasarinya.

Setiap teori memiliki kerangka kerja (theoretical framework) yang lazim disebut metodologi, sehingga setiap teori berkonsekuensi metodologis tertentu. Berbeda teori akan berbeda metodologinya. Dalam bangunan keilmuan, metodologi merupakan aspek logis dan objektif yang memungkinkan temuan-temuan ilmiah dapat diterima (atau ditolak) secara rasional dan objektif. Itulah sebabnya, metodologi sering dimaknai sebagai logic of discovery (logika penemuan). Dengan begitu, metodologi berbeda dengan metode yang maknanya adalah process and prosedure. Bedanya, yang disebut pertama bersifat filosofis, sedang yang disebut belakangan bersifat teknis. Dalam kegiatan keilmuan, sekalipun keduanya tak dapat dipisahkan, namun tetap memiliki wilayahnya sendiri-sendiri.

Jika dalam filsafat ilmu ditemukan beberapa teori, itu berarti tersedia beberapa tawaran metodologi sebagai kerangka dalam proses keilmuan. Hal ini, harus dipahami bahwa masing-masing teori, tengah 'berdiskusi' tentang persoalan metodologi. Karena setiap teori memang menyediakan logic of discovery sesuai dengan kerangka logikanya masing-masing. Setiap teori berkonsekuensi metodologis tertentu. Dalam kegiatan keilmuan, metodologi harus dipahami sebagai 'kaca mata' atau perspektif dalam membaca, memahami dan menafsirkan objek ilmu pengetahuan, sehingga 
fakta dapat ditata dan dipetakan menjadi data sesuai dengan karakteristiknya berdasarkan peta pikir (mind mapping, dalam istilah quantum learning) suatu teori tertentu. Fakta atau data akan sulit ditemukan jalinan konsistensinya, jika tidak dibaca, ditata dan dikerangkakan dengan sarana metodologi atau perspektif tertentu.

Dalam prakteknya misalnya terlihat dalam beberapa karya ilmiah, buku, dalam ceramah-ceramah, atau khutbah, yang terkadang ditemukan uraian yang sulit ditemukan ujung pangkalnya, sulit dimengerti, ini karena data tidak ditata dalam kerangka yang jelas. Ini artinya, peran ilmu pengetahuan untuk menyederhanakan kompleksitas fakta atau peristiwa, tidak berjalan sebagaimana mestinya. Dengan demikian, lebih jauh dapat dipahami, bahwa metodologi juga merupakan persoalan komunikasi. Dalam pengertian bahwa dengan metodologi, membuat pengetahuan kita tentang fakta dapat kita komunikasikan dengan orang lain. Meski harus diingat bahwa komunikasi bukanlah sekedar saling bicara, apalagi "yang penting disampaikan" (secara monolog), namun lebih menekankan pada saling memahami, dalam arti, apa yang disampaikan bisa dipahamkan dan karenanya juga dapat dipahami.

Berkaitan dengan problem komunikasi ini, 'kerja' suatu metodologi ditunjukkan dengan penggunaan istilah-istilah kunci (keyword) yang menjadi 'hak paten' dari teori tertentu. Dengan metodologi, fakta yang panjang-lebar dan "semrawut" bisa dikomunikasikan secara sederhana, hanya dengan menggunakan istilah-teoritis tertentu. Oleh karena itu pemahaman terhadap definisi operasional (?) istilah-teoritis sangat diperlukan, agar tidak terjadi kesalahpahaman, yang sudah pasti akan mengarah pada kesalahan langkah. Menyomot istilah-teoritis tanpa disertai pemahaman, berarti telah melakukan tindakan ceroboh, dan bisa saja disebut melakukan eksploitasi teori, yang memang sudah menjadi 'hak cipta' dari para ilmuwan atau filsuf sebagai penemu teori tersebut.

Sementara paradigma ilmiah adalah pola pikir kolektif ilmuwan (scientific community) yang menjadi basis tumbuh kembangnya segala aktivitas keilmuan. Pada sisi yang lain, paradigma juga dapat dipahami sebagai tempat bernaung teori-teori. Dalam bangunan keilmuan, paradigma merupakan basis sosiologis, 
antropologis, dan historis sains. Sehingga posisi eksistensi ilmuwan sebagai manusia tidak diabaikan begitu saja, dan sebaliknya, bahkan diakui sebagai bagian tak terpisahkan dalam bangunan keilmuan. Bersatunya para ilmuwan dalam kolektifitasnya dan menyatunya teori-teori dalam satu paradigma didasarkan pada adanya ikatan logis maupun sosiologis-historis. Berbeda dengan teori yang dapat dijatuhkan, paradigma ilmiah, karena bernaung di bawahnya banyak teori dan didukung oleh scientific community maka tidak bisa dijatuhkan begitu saja. Perubahannya memiliki proses tersendiri. Kalaupun harus dikritik, bukanlah pada paradigmanya, tetapi lebih terkait pada alasan pemilihannya.

Sedangkan asumsi dasar adalah sisi terdalam dari bangunan keilmuan. Sifatnya lebih halus dari paradigma dan teori. Dalam bangunan keilmuan, asumsi dasar dimaksudkan sebagai basis teologis-metafisis, karena memang terkait dengan keyakinan atau bahkan keimanan ilmuwan. Dalam perspektif "filsafat ilmu" klasik, posisi basis teologis-metafisis ini bisa diidentikkan dengan "premis mayor" sebagaimana dalam logika tradisional Aristoteles, atau berkedudukan sebagai "idea transendental" sebagaimana epistemologi Immanuel Kant. "Idea transendental" ini merupakan cita yang menguasai segenap pemikiran..$^{23}$ Idea ini sifatnya semacam "indikasi-indikasi kabur", yang berupa petunjuk-petunjuk yang membimbing "akal murni" dan "akal praktis. Seperti juga kata "barat" dan "timur" yang merupakan petunjuk-petunjuk: "timur” an sich tidak pernah bisa diamati. Kaitannya dengan pengembangan ilmu, idea transendental itu merupakan "postulat" atau "aksioma" 24 yang berperan sebagai asumsi, orientasi dan arah bagi kerja ilmiah. Oleh karena itu, keberadaannya di luar jangkauan pembuktian teoretis-empiris. ${ }^{25}$

${ }^{23}$ Sifat idea ini, menurut Kant: inteligible, clear, and decisive..... the transcendental ideas therefore express the peculiar application of reason as a principle of systematic unity in the use of understanding. Lihat Immanuel Kant, Prolegomena to Any Future Metaphysics, terj. The Paul Carus, revisi oleh James W. Ellington (Indianapolish/Cambridge: Hackett Publishing Company, 1977), h. 89-90

${ }^{24}$ Lihat, F. Budi Hardiman, Filsafat Modern, dari Machiavelli sampai Nietzsche, (Jakarta: PT Gramedia Pustaka Utama, 2004), h. 143

${ }^{25}$ Menurut Kant, ada tiga Idea transendental. Pertama Idea psikis (jiwa) yaitu merupakan gagasan mutlak yang mendasari segala gejala batiniah. Kedua, gagasan yang menyatukan segala gejala lahiriah, yakni Idea kosmologis (dunia). Dan akhirnya, 
Sementara dalam perspektif Filsafat Ilmu kontemporer, asumsi dasar itu justru menjadi "inti" (hard core) dalam segala aktivitas ilmiah sebagaimana ditawarkan Lakatos. Hard core bersifat negative heuristic sehingga tidak bisa dikritik atau disalahkan. Posisinya sangat kuat karena dijamin oleh protective belt (lingkaran pelindung). Di luarnya masih terbangun sejumlah teori yang secara koheren saling mendukung dan berkembang sesuai dengan perkembangan hipotesa (auxillary hypotheses). Teori-teori ini bersifat positif heuristic yang berkemungkinan bisa berkembang dan disalahkan. Hard core, negative heuristic dan protective belt dalam konsepsi Lakatos inilah yang memungkinkan sains yang berbasis agama seperti sains Islam menjadi bangunan keilmuan yang ilmiah. Lebih dari itu, menempatkan kata Islam di belakang kata Sains kemudian terkesan menjadi sangat wajar dan tidak aneh.

Model pengembangan sains seperti ini sudah tentu berbeda dengan model justifikasi Bucaillian yang beresiko menyalahkan ayatayat kitab suci jika teori terbukti salah sebagaimana diprihatinkan para pemerhati sains Islam. Maka jika harus mengutip sebagian ayat kitab suci, itu sudah tentu dalam kerangka menguatkan asumsi teologis-metafisis dari bidang yang sedang dikaji, yang posisinya sebagai asumsi dasar dan dilindungi oleh protective belt.

Sudah tentu asumsi teologis-metafisis yang dimaksud di sini terkait dengan konsep asasi, seperti hakikat kehidupan, dunia, ilmu, dan bahkan keagamaan dan ketuhanan. Beberapa hal ini bisa disebut fundamental elements of the worldview. Maka Islamic worldview sebagaimana dimaksudkan oleh Alparslan dan al-Attas, dalam perspektif Filsafat Ilmu, tidak lain merupakan basis teologismetafisis atau hard core atau premis mayor atau ide transendental

\footnotetext{
gagasan yang mendasari segala gejala, baik yang lahiriah maupun yang batiniah, yaitu yang terdapat dalam suatu pribadi mutlak, yakni Tuhan sebagai Idea Teologis. Kendati Kant menerima ketiga Idea itu, ia berpendapat bahwa ide-ide itu tidak bisa diketahui lewat pengalaman. Lihat S.H. Lili Tjahyadi, Hukum Moral, Ajaran Immanuel Kant tentang Etika dan Imperatif Kategoris, (Yogyakarta: Kanisius, 1991), h. 38-39; Dengan Kritiknya ini, Kant sekaligus menunjukkan kekeliruan argumen ontologis, kosmologis dan teleologis dalam metafisika tradisional yang dikatakan dapat membuktikan adanya Tuhan. Menurut Kant, argumen metafisika tradisional itu telah jatuh ke dalam paralogisme (penalaran sesat). Bagaimana kekhasan argumenargumen tersebut dan bagaimana kritik Kant, lihat Amsal Bakhtiar, Filsafat Agama, (Jakarta: Logos Wacana Ilmu, 1997), h. 169-188.
} 
dalam keilmuan Sains Islam. Inilah yang membedakan sains yang berbasis agama Islam dengan sains yang berbasis agama lain, atau dengan sains yang tidak berbasis agama, jika ada. Dalam diskursus pemikiran Islam kontemporer, asumsi teologis-metafisis ini bisa diidentikkan dengan problem al-sawābit (yang mapan) sementara paradigma dan teori bisa diidentikkan dalam wilayah al-mutahawwil (yang berubah), sekalipun ada perbedaan dalam perubahannya. ${ }^{26}$

Dengan begitu, penolakan, apriori, sikap ragu dan pesimistik terhadap lahirnya Sains Islam telah mendapat jawabannya dari sudut pandang filsafat ilmu. Sekedar mempertegas lagi, bahwa dalam perpektif filsafat ilmu kontemporer, terdapat tiga model pengembangan sains, pertama, pengembangan sains yang menekankan pada basis metodologi ilmiah. Ini jelas kontribusi Francis Bacon dan Positivisme. Bagi ilmuwan yang hanya mengakui metodologi ilmiah dan teori sebagai basis filosofis sains, sudah tentu mereka menolak adanya sisi sosiologis-historis dari sains, apa lagi sisi teologis-metafisisnya; kedua pengembangan sains yang memberi penekanan pada basis metodologi ilmiah plus basis sosio-historis. Ini merupakan jasa dari Thomas Kuhn. Pengakuan adanya paradigma ini meniscayakan ilmuwan untuk memahami bahwa sains itu juga human and social construction.

Dan, model ketiga, pengembangan sains yang sekaligus memberi penekanan pada tiga elemen filsafat keilmuan, yaitu: basis metodologi ilmiah, basis sosio-historis, dan basis teologis-metafisis. Yang terakhir ini merupakan kontribusi Lakatos. Pengembangan sains pada model ketiga itulah yang memungkinkan sains yang berbasis agama seperti Sains Islam menjadi ilmiah. Atau dengan kata lain, keyakinan bahkan keimanan Islam sebagai basis teologismetafisis ilmuwan telah memiliki posisi yang jelas sebagai bagian tak terpisahkan dalam bangunan keilmuan. Untuk lebih jelasnya tiga model pengembangan sains ini dapat digambarkan pada tabel berikut:

${ }^{26}$ Lihat Adonis, Al-Ṣābit wa al-Mutahawwil: Baḥs fī al-Ibdā' wa al-Ittibā' inda $a l-A r a b$ (Yang Mapan-Statis dan Yang Berubah-Dinamis: Kajian atas kreativitas dan konservativitas menurut bangsa Arab). Buku ini telah diterjemahkan ke dalam bahasa Indonesia oleh Khoiron Nahdiyin dengan judul: Arkeologi Sejarah Pemikiran Arab-Islam, (Yogyakarta: LKiS, 2007). 


\begin{tabular}{|c|c|c|}
\hline Model I & Model II & Model III \\
\hline Basis Metodologi & Basis Metodologi & Basis Metodologi \\
Ilmiah & Ilmiah & Ilmiah \\
\hline & Basis Sosio-Historis & Basis Sosio-Historis \\
\hline & & Basis Teologis-Metafisis \\
\hline
\end{tabular}

\section{E. Penutup}

Dalam perspektif Filsafat Ilmu, keilmiahan dari bangunan keilmuan atau aktifitas ilmiah pada umumnya memang sangat ditentukan oleh ketepatan dalam penggunaan teori dan pada akhirnya juga metodologinya. Ketepatan itu dapat diukur dari terbukanya perspektif baru dan perspektif yang lebih luas dari teori sehingga ditemukan lebih banyak bukti pendukungnya, juga diukur dari ketahanannya dari proses falsifikasi dan refutasi. Namun demikian tetap tidak mengabaikan sisi-sisi sosiologis-historis dari paradigma ilmiah, juga sisi teologis-metafisis dari asumsi dasar. Karena bagaimanapun ketiganya merupakan bagian tak terpisahkan dari bangunan kailmuan. Jika yang pertama merupakan basis logis dan objektifitas sains, lalu yang kedua merupakan aspek kemanusiaan dari sains, maka yang ketiga adalah basis keyakinan, keimanan, dan keberagamaan dari sains.

Dengan berbasiskan tiga elemen penting Filsafat Ilmu itu, Sains Islam yang dimengerti sebagai sains berbasis agama Islam itu jelas mungkin menjadi ilmiah. Sekalipun demikian, definisi baru Sains Islam sebagai aktivitas ilmiah mesti terus dilanjutkan kearah "action" program riset. Dengan begitu, Sains Islam akan menghasilkan temuan-temuan baru, teori baru, metodologi baru, konteks baru, dan seterusnya. Tanpa upaya itu, image pseudosains dan justifikasi Bucaillian akan sulit hilang dari bangunan keilmuan Sains Islam.[]

\section{Daftar Pustaka}

Adonis, As-Ṣābit wa al-Mutahawwil: Bahṣ fì al-Ibdà' wa al-Ittibā' inda alArab, terj. Khoiron Nahdiyin Arkeologi Sejarah Pemikiran ArabIslam, Yogyakarta: LkiS, 2007. 
Arif, Syamsudin, “Transmigrasi Ilmu: Dari Dunia Islam ke Eropa”, dalam Tsaqafah, Jurnal Peradaban Islam, Vol. 6 No. 2, Oktober 2010.

al-Asyqar, Muhammad Sulayman, al-Mustasyfa, Beirut: Mu'assasah alRisālah, 1997.

Bakhtiar, Amsal, Filsafat Agama, Jakarta: Logos Wacana Ilmu, 1997.

Bertens, K., Filsafat Barat Abad XX: Inggris-Jerman, Jakarta: Gramedia, 1983.

Bucaille, Maurice, Bibel, Qur'an dan Sains, terj. A. Rasyidi, Jakarta: Bulan Bintang, 1992.

Corbin, Henry History of Islamic Philosophy, London and New York: Kegan Paul International, 1962.

Edwards (ed), Paul, The Encyclopedia of Philosophy, New York: The Macmillan Company and The Free Press, 1967.

Foucault, Michel, The Order of Think: An Archeology of Human Sciences, New York: Vintage Books, 1994.

Al-Gazali, al-Mustasyfa min 'Tlm al-Ușūl, Kairo: Maktabah al-Amiriyyah, 1904.

Gutting (Ed.), Gurry, Paradigms and Revolutions: Appraisals and Applications of Thomas Kuhns Philosophy of Science, Notre Dame: University of Norte Dame Press, 1980.

Hamat, Mohd Fauzi “Kedudukan Mantiq Sebagai Muqaddimah Ilmu: Satu Analisis Pandangan Imam Al-Gazali”, dalam Afkar, Jurnal Akidah \& Pemikiran Islam, Bil.3: Rabiu al-Awwal 1423/Mei - Jun 2002.

Hardiman, F. Budi, Filsafat Modern, dari Machiavelli sampai Nietzsche, Jakarta: PT Gramedia Pustaka Utama, 2004.

Al-Jabiri, Abed, Bunyah al-'Aql al-'Arabi, Beirut: Markaz Dirāsah alWahdah al-Arabiyyah, 2004. , Takwīn al-'Aql al-'Arabi, Beirut: Markaz Dirāsah al-Wahdah al-'Arabiyyah, cet. VIII, 2002.

Lakatos, Imre dan Mosgrave (Ed.), Alan, Criticism and the Growth of Knowledge, Cambridge: Cambridge University Press, 1974.

Madjid, Nurcholish, Khazanah Intelektual Nurcholish Islam, Jakarta: Bulan Bintang, 1984. 
Muslih, M., Filsafat Ilmu; Kajian atas Asumsi Dasar, Paradigma, dan Teori Dasar Imu Pengetahuan, Yogyakarta: Belukar Budaya, 2005.

Popper, Karl R., Logic of Scientific Discovery, New York: Harper and Row, Harper Torchbooks, 1965.

Rusyd, Ibn, Faṣl al-Maqāl fì Taqrīr mā Bayn al-Syarīah wa al-Hikmah min al-Ittișāl, tahqiq Abid al-Jabiri, Libanon: Markaz Dirāsah alWahdah al-Arabiyah, 2007.

Sidik, Abdullah, Islam dan Filsafat, Jakarta: Triputra Masa, 1984.

Sutrisno F.X Mudji dan F. Budi Hardiman, Para Filsuf Penentu Gerak Zaman, Yogyakarta: Kanisius, 1994.

Taryadi, Alfons, Epistemologi Pemecahan Masalah Menurut Karl Popper, Jakarta: PT Gramedia Pustaka Utama, 1991. Kant, Immanuel, Critique of Pure Reason, Translated by JMD. Meiklejohn, New York: Prometheus Books, 1990.

, Prolegomena to Any Future Metaphysics, terj. The Paul Carus, revisi oleh James W. Ellington, Indianapolish/Cambridge: Hackett Publishing Company, 1977.

Tjahyadi, S.H. Lili, Hukum Moral, Ajaran Immanuel Kant tentang Etika dan Imperatif Kategoris,(Yogyakarta: Kanisius, 1991. 